\title{
"Strange beasts of the sea": Captain Cook, the sea otter and the creation of a transoceanic American empire
}

\section{Juliane Braun}

To cite this article: Juliane Braun (2018) "Strange beasts of the sea": Captain Cook, the sea otter and the creation of a transoceanic American empire, Atlantic Studies, 15:2, 238-255, DOI: 10.1080/14788810.2017.1387462

To link to this article: https://doi.org/10.1080/14788810.2017.1387462

曲 Published online: 13 Mar 2018.

Submit your article to this journal $₫$

山 Article views: 5

Q View related articles $\square$

View Crossmark data ¿ 


\title{
"Strange beasts of the sea": Captain Cook, the sea otter and the creation of a transoceanic American empire
}

\author{
Juliane Braun \\ Department of English, American, and Celtic Studies, University of Bonn, Bonn, Germany
}

\begin{abstract}
On 12 July 1776, Captain James Cook and his crew left England in search of the famed Northwest Passage. Spanish, French, and Russian explorers before him had set out to find this Arctic waterway, which was thought to link the Atlantic and the Pacific Oceans and promised to open up a new, more direct trading route with Asia. After seven months of sailing up and down the North American Pacific Coast, however, Cook was forced to conclude that such a passage did not exist. His voyage nonetheless transformed the trade relations between Europe, the USA, and Asia. By detailing the rich natural resources the crew encountered in the North Pacific, the published records of Cook's last voyage alerted a vast reading public, both in Europe and the young USA, to the commercial opportunities emerging from the exploitation of these resources. Using the example of the sea otter, this article explores how new knowledge about the natural world in the Pacific and its dissemination through print culture not only sparked intense rivalries between European colonial powers, but also helped the newly independent USA establish itself as a transoceanic empire.
\end{abstract}

\section{KEYWORDS}

Transoceanic; Pacific natural environment; print networks; exploitation; early American empire

On 12 July 1776, Captain James Cook and his crew left England in search of the famed Northwest Passage. Spanish, French, and Russian explorers before him had set out to find this Arctic waterway, which was thought to link the Atlantic and the Pacific Oceans and promised to open up a new, more direct trading route with Asia. After seven months of sailing up and down the North American Pacific Coast, however, Cook was forced to conclude that such a passage did not exist. His voyage nonetheless transformed the trade relations between Europe, the USA and Asia. By detailing the rich natural resources the crew encountered in the North Pacific, the published records of Cook's last voyage alerted a vast reading public, both in Europe and the young USA, to the commercial opportunities emerging from the exploitation of these resources. Using the example of the sea otter, this article explores how new knowledge about the natural world in the Pacific and its dissemination through print culture not only sparked intense rivalries between European colonial powers, but also helped the newly independent USA establish itself as a transoceanic empire. 
Historians and critics have called the eighteenth century "the Second Great Age of Discovery" because it was marked by numerous large-scale scientific voyages into the Pacific. ${ }^{1}$ In quick succession, the Dutch, Russian, English, French, and Spanish governments and a number of private sponsors sent out maritime expeditions in search of the great Southern continent, unknown waterways, and secret islands. Spurred by the Scientific Revolution and Enlightenment thinking, the pursuit of knowledge and travel to distant worlds became inextricably linked. Unlike the Renaissance Age of Discovery, this Second Great Age of Discovery, it seemed, was less about conquest, colonization, and exploitation, and more about obtaining information, gathering knowledge and advancing science. ${ }^{2}$ Recent scholarship, however, has emphasized the connections between eighteenthcentury maritime voyages of discovery, the quest for knowledge, and imperial agendas. "European powers," historian Daniela Bleichmar writes, "undertook the exploration of distant natures as a matter of key economic, political, and scientific importance." ${ }^{3}$ And David Igler adds that "science served a general imperial agenda, including commercial, geopolitical, and scientific goals." ${ }^{4}$

In the eighteenth century, the Pacific emerged as a crossroads of empire where Dutch, Russian, English, French, Spanish, and American interests competed, collided, and converged. In 1721, for example, the Dutch West India Company deployed Jacob Roggeveen on a voyage in search of Terra Australis, and in 1732 the Russian Empire ordered an ambitious expedition into Siberia and North East Asia that was designed to map these areas and parts of the North American shoreline. Three decades later Captain James Cook undertook three voyages to explore large portions of the Pacific Ocean on behalf of the English Crown, while the scientific expeditions of Louis Antoine de Bougainville and Jean-François Galaup de la Pérouse enabled the French government to establish commercial and political presences across the great South Sea. Only shortly thereafter, Alessandro Malaspina set out to survey the Spanish possessions in the Americas and in Asia, and by the end of the eighteenth-century, the first US American ships ventured into the North Pacific, creating American outposts near the mouth of the Columbia River and establishing a vibrant maritime trade with China. ${ }^{5}$

Despite the centrality of the Pacific Ocean in the eighteenth century, it has received relatively little attention from American studies scholars. ${ }^{6}$ A recent surge in the study of transpacific literary and cultural relations has produced insightful work on Antipodean America, the US pivot to Asia, and the Black Pacific, but scholarship on the many formations, characteristics, and iterations of the Atlantic world remains dominant." "The Atlantic world has occupied a privileged but settled space in constructing US history and narratives from the country's founding to the end of the so-called American century," Yuan Shu and Donald E. Pease write in their introduction to American Studies as Transnational Practice: Turning toward the Transpacific, and John Carlos Rowe asserts in his contribution to that volume that unlike the Atlantic, "the Pacific has remained relatively undertheorized in terms of the imperial narrative." ${ }^{8}$

The study of US imperialism especially has been dominated not only by Atlanticist perspectives but also by so-called continental approaches to early American history and culture. In an attempt to decenter the traditional east-west narrative of exploration and settler colonialism, scholars working with a continental framework seek to integrate the western parts of the American continent into their accounts of early American history, often focusing explicitly on the effects of colonialization on the continent's native 
populations. ${ }^{9}$ Such an approach, however, as its name suggests, remains decidedly landlocked. ${ }^{10}$ But as an entity bounded by two oceans, the American continent and its peoples have always also looked towards the seas. Goods, ideas, and people have traversed the oceans in multiple directions, creating networks that transcend territorial entities and establish surprising connections between distant and seemingly unrelated sites. In order to tease out these relations and their influence on the American continent both in spatial and in temporal terms, literary historian Michelle Burnham has recently argued for a "transoceanic paradigm that connects the early Pacific to its Atlantic counterpart in the long (and wide) encounter between European empires and indigenous New World peoples." ${ }^{11}$

In this article, then, I explore what it means to use a transoceanic, rather than an Atlantic, Pacific, or continental lens for the study of early America. By tracing how new knowledge about recent discoveries in the Pacific was disseminated through an Atlantic publishing network, I will illustrate the consequences of the transoceanic circulation of ideas not only for the Pacific natural environment, but also for the political orientation of the early USA. ${ }^{12}$ Through an analysis of the publication, circulation, and reception of the narratives emanating from Captain Cook's last voyage, I demonstrate how a comparative study of Atlantic print culture and publishing networks can bring into relief the imperial dimensions of early American government policies and the colonialist actions of private entrepreneurs. Ultimately, I contend that we should discuss the Early Republic not only in terms of an Atlantic, Pacific, or continental nation, but, more accurately, to recognize it as a transoceanic empire. ${ }^{13}$

\section{The beginnings of transoceanic empire}

The seeds of the transoceanic empire were planted when, between 1741 and 1743, the German naturalists Georg Wilhelm Steller and Gerhard Friedrich Müller traveled to Siberia as members of the Second Kamchatka Expedition, a venture commissioned by Empress Anna Ivanovna and carried out under the leadership of the Danish explorer Vitus Bering. The expedition was designed to survey the northernmost coast of the Russian empire, explore the peninsula of Kamchatka, and find new waterways to Japan and America across the North Pacific Ocean. ${ }^{14}$ From the start, the expedition's goal was not only to produce new knowledge about this region, but also to find new opportunities for profit and commercial gain. The naturalists participating in these expeditions were directly involved in finding such opportunities for profit. They were, according to Gerhard Friedrich Müller, supposed to research

the natural condition of any area of lands; its fertility and other qualities, its positive and negative attributes [...] what animals, birds, and fish live in what places and where what grasses, bushes, and trees can be found and whether any of them can be used for medicines or paints or some other economic purpose [...]. ${ }^{15}$

Müller and Steller both faithfully followed these directives, taking copious notes that detailed their observations on the Nordic flora and fauna, the potential for mineral wealth, and the characteristics of the indigenous populations.

In 1751 some of Steller's notes were published in St. Petersburg as De Bestiis Marinis ("On the Beasts of the Sea") and, two years later, appeared in German as Ausführliche 
Beschreibung von sonderbaren Meerthieren ("Detailed Description of Strange Beasts of the Sea"). Among the "strange beasts of the sea" he described, Steller dedicated almost 50 pages to the sea otter (Enhydra lutris), a marine mammal that can be found near the shore of the North Pacific Coast. Sea otters spend most of their time in the water, where they typically form rafts of up to a 100, and only rarely venture on land. For his initial description of this new species Steller, like many before him who had encountered unfamiliar lands, peoples, plants, and animals, relied largely on comparison:

Its size was that of an average dog, its head slightly round, almost like a cat's head, with a more pointed nose, the eyes [were] black and round, the ears pointed and round. It has a beard; the feet have five claws equipped with brownish-black and pointed nails, the innermost claw is shorter than the others; the fur is soft and black. Its wails resemble those of young dogs; it feeds off of crab and fish. ${ }^{16}$

On the following pages, Steller gave details on the measurements of the sea otter, its "shape," "external parts," and "internal parts."17 Again and again, however, Steller returned to the sea otter's beauty: "I cannot praise the beauty of such a live animal enough," Steller noted, and continued:

If it walks on land, it is blacker than black velvet or silk, and gleams in different shades of black. Because its skin is not tight, but loose on its body, it moves and, as the animal is in motion, produces glossy shades of black that are ever different. ${ }^{18}$

In these and similar descriptions in Steller's sea otter chapter, it becomes obvious that the supposed beauty of this marine mammal is explicitly linked to its fur, and, more specifically, to the commercial promise of its pelt. "The animal's skin is thick," Steller elaborated, and "covered in very soft, luxuriant hair, making it incredibly expensive." ${ }^{19}$ Steller's subsequent chapter on "The Behavior of the Sea Otter," then, only provided very few insights into how the sea otter acts in its natural surroundings, but mostly consisted of a detailed study of its fur coat, the different approaches to hunting and killing it, and a description of the various ways of de-skinning and processing the pelts effectively. ${ }^{20}$ In the end, Steller and his companions could not resist trying out these techniques themselves. As they departed from the Aleut Islands, the members of the expedition had killed more than 800 sea otters. "And if our ship had not been so small," Steller confessed, "we would have liked to kill three times as many." ${ }^{21}$ What had started out as an exploration of the natural environment in the North Pacific had ended in a killing spree that marked the beginning of large-scale sea otter hunts, and the relentless pursuit of other "strange beasts" of the North Pacific.

Almost 40 years after the conclusion of the Second Kamchatka Expedition, the English reverend and historian William Coxe published An Account of Russian Discoveries between Asia and Russia (1780), a volume designed to offer, in Coxe's own words, "the most authentic and circumstantial account of the progress and extent of the Russian discoveries, which has hitherto appeared in any language."22 Until the publication of Coxe's work, the Russian Empire had not publicly released any information about its activities in the North Pacific, but with the latest encroachment of the English and their celebrity navigator Captain James Cook, the Russian imperial magistrates felt they needed to validate their claims and inform a greater European public about their discoveries in the Aleut Islands and Alaska. They granted Coxe access to their archives, allowing the Englishman to 
produce a volume that detailed the Russian forays into the North Pacific and confirmed their precedence in the Aleut Islands and Alaska. ${ }^{23}$

Drawing on the early work of Steller and Müller, but also incorporating new material about the Russian Pacific voyages since the Second Kamchatka Expedition, Coxe produced a volume that enabled "the curious and inquisitive reader" to compare the Russian discoveries "with those more lately made by that great and much to be regretted navigator, Captain Cooke." ${ }^{24}$ As he prepared his manuscript Coxe noticed that his sources repeatedly mentioned the existence of an active trade between the Russians and the Chinese, in the course of which "all the furs which are brought from the New Discovered Islands are sold the Chinese." 25 Making his own enquiries into the exact nature of the exchange, Coxe found "this branch of traffic much more important than is commonly imagined" and included "a general sketch of its present state" and "a succinct view of the transactions between the two nations" in his volume. ${ }^{26}$ His treatise of the Russo-Chinese fur trade focused mainly on the sea otter skin, revealing, for the first time, to an English-speaking public, the enormous commercial opportunities the North Pacific offered. While he dedicated less than a page to the description of the animal's physiognomy and fur, he reported in detail on the value of the pelts. "The skins fetch different prices according to their quality," Coxe explained and continued: "At Kamchatka the best sell for [...] 30 to 40 Roubles, [...] the worst sort [for] 15 to 25." In the Russian border town of Kiachta, however, "the old and middle-aged sea otter skins are sold to the Chinese per skin from 80 to 100, the worst sort [for] 30 to 40." "As these furs fetch so great a price to the Chinese," Coxe concluded, "they are seldom brought into Russia for sale."27

Almost immediately after the first edition of Coxe's Account of Russian Discoveries was published, a second, "revised and corrected" edition appeared, updating the information that was available on the Russian sea otter skin trade. In 1781, Coxe's volume was published in Paris as Nouvelles Découvertes des Russes entre l'Asie et l'Amérique, and in 1783, a German version followed. By disseminating the findings of the Russian North Pacific expeditions across three European countries, the publication of Coxe's work offers an early example of how print created transoceanic connections by bringing the accounts of North Pacific maritime voyages to the Atlantic world. Coxe's 1780 Account, however, only reached a limited expert audience. It was the publication of the official account of Captain Cook's third voyage four years later that finally spread the word about the sea otter and its enormous commercial potential across Europe and in the Americas.

\section{An international bestseller: James Cook's Voyage to the Pacific Ocean}

James Cook and his crew left England in 1776 on a government-sponsored voyage to explore the last unknown regions of the Pacific Ocean, hoping to finally prove or disprove the existence of the Northwest Passage. Though initially a success - the men discovered Hawai'i and surveyed long stretches of the North Pacific coastline - the expedition soon ran into problems. Ice, unfavorable winds, and bad visibility prevented the men's advances in the North, and when they returned to Hawai'i to winter the crew's once friendly relationship with the islanders quickly deteriorated. On 14 February 1779 , an armed confrontation between the Hawai'ians and Cook's crew resulted in the death of many islanders, four expedition members, and the famous captain. ${ }^{28}$ 
When the remaining crewmembers finally returned in 1780, the news of Cook's death had already reached England and the English public was eager to find out more about the exact circumstances. To prevent the distortion of Cook's public image and the misrepresentation of the expedition's scientific findings, the Admiralty quickly began to prepare an officially sanctioned account of the voyage. Dr John Douglas, a high official of the Anglican Church who had already edited the journals of Cook's second voyage, was charged with preparing the work for publication. Battling an incomplete manuscript and high public expectations, it took Douglas four years to publish the authorized version. The book appeared in London in 1784 as A Voyage to the Pacific Ocean and amounted to three volumes comprised of 1617 pages, an atlas, and 87 plates that illustrated some of the most important occurrences and encounters of the voyage. ${ }^{29}$ The frontispiece informed the readers that the first and second volumes were "written by Captain James Cook," and the third volume was penned by naval officer James King, but Douglas had altered Cook's and King's journals considerably during the editorial process. The official publication was thus a highly mediated account of Cook's third and last voyage, communicating to its readers a version of the circumnavigation that was sanctioned and endorsed by the British Admiralty. ${ }^{30}$

Despite its relatively high price of $£ 4,14 s, 6 d$, the book quickly sold out. ${ }^{31}$ "We remember not a circumstance like what has happened on this occasion," the Monthly Review wrote. "On the third day after publication, a copy was not to be met with in the hands of the bookseller; and, to our certain knowledge, six seven, eight, and even ten guineas, have since been offered for a set." ${ }^{\prime 32}$ Within weeks, numerous subsequent editions, abridged versions, collections, and even children's books followed. Selected installments of $A$ Voyage to the Pacific Ocean also appeared in periodicals, such as the Gentleman's Magazine and the Critical Review. ${ }^{33}$ Before 1800, the official account of Cook's last voyage was translated into French, German, Dutch, Swedish, and Italian, and almost every new English edition was followed by a new translation. In the USA, editions of the account of Cook's last voyage appeared, among other places, in Philadelphia, Worcester, New York, and Boston. The book was, in modern terms, a bestseller. ${ }^{34}$

For the following analysis, I have studied two versions of the narrative of Captain Cook's third voyage: the 1784 official account, and an unofficial narrative penned by the American John Ledyard, who had participated in the expedition as a mid-ship man. Juxtaposing these accounts with the Spanish, French, and American reactions to the expedition's findings demonstrates how the news about the profitability of the sea otter skin trade shaped governmental policies and private hunting and trading practices for decades, contributing immensely to the formation of the early USA's decidedly transoceanic outlook.

In Douglas' account, Cook and his crew seemed to have known about the sea otter and its profitable pelt before they embarked upon their journey, for they had studied "the accounts of the Russian adventures." ${ }^{135}$ However, when members of the indigenous population brought out skins to barter, the crew "entertained doubts, whether the many skins [...] really belonged to this animal, as our only reason for being of that opinion, was founded on the size, colour, and fineness of the fur." ${ }^{36}$ No member of the expedition had yet seen a whole dead specimen, let alone a live animal. When the crew finally had an opportunity to buy a whole dead sea otter, the expedition's artist John Webber "made a drawing" for future reference, and then took it apart in order to study its anatomy. ${ }^{37}$ But even this whole specimen "seem[ed] to disagree with those found by 
the Russians." ${ }^{38}$ It had too many teeth, the toes lacked a membrane, and the color was not right. Rather than the jet-black coat, the dead specimen sported "a greyish cast," and its "face, throat, and breast were of a yellowish white, or very light brown colour." ${ }^{39}$

Although Cook and his crew could not be sure they had actually encountered sea otters or sea otter furs, Douglas' account included a reference to the supposed value of the pelts: "The fur of these animals," it stated,

is certainly softer and finer than that of any others we know of; and, therefore, the discovery of this part of the continent of North America, where so valuable an article of commerce may be met with, cannot be a matter of indifference." ${ }^{40}$

But it was not until the expedition's arrival in Canton, China six months later that the members of the expedition could finally be sure that the furs they had loaded onto their ships were indeed the furs of the sea otter and in high demand. One crewmember "sold his stock, alone, for eight hundred dollars, and a few prime skins, which were clean, and had been well preserved, were sold for one hundred and twenty each." ${ }^{41}$ These transactions confirmed what had previously only been a rumor: sea otter skins commanded high prices in the Russian border town of Kiachta, but they could be sold for even more in Canton. For the members of Cook's expedition, the sea otter had become an enormously profitable natural resource, quickly earning its pelts the moniker of "soft gold." ${ }^{42}$ This prospect of fast money almost derailed the remainder of the expedition. "The rage with which our seamen were possessed to return to the Cook's River, and, by another cargo of skins, to make their fortunes, at one time, was not far short of mutiny," naval officer James King reported in $1778 .^{43}$ In 1779, two sailors deserted because they "had been seduced by the prevailing notion of making a fortune, by returning to the fur islands," and Captain King himself thought out an elaborate trading scheme designed to integrate the Chinese sea otter trade into the transactions of the English East India Company. ${ }^{44}$

All of the five European editions and translations of the official account of Cook's third voyage I have consulted contain these descriptions of the sea otter skin trade in Canton. ${ }^{45}$ Even editions that were "faithfully abridged" by editors who otherwise cut what they thought insignificant or excessive included the sea otter episodes. ${ }^{46}$ Similarly, of the 11 American editions that appeared before 1820, seven included significant passages about the sea otter and its commercial promise. ${ }^{47}$ Within 10 years of the official account's first publication, then, the news of the profitability of the sea otter skin trade had traveled, among other places, from London to Dublin, Paris, Rotterdam, Turin, Berlin, Anspach, Turin, Philadelphia, Worcester, New York, and Boston.

\section{From John Ledyard's Journal to Thomas Jefferson's pacific aspirations}

Through the publication, re-edition, and translation of $A$ Voyage to the Pacific Ocean, government officials in Europe and the USA learned about the enormous profits to be made from the sea otter skin trade. Almost immediately, several governments launched their own sea otter initiatives. For example, in 1786 the Spanish Crown established a "Philippine Company" that traded sea otter furs harvested in California, while the French Ministère de la Marine sent out Jean-François Galaup de la Pérouse to assess firsthand the profitability of a government-sponsored sea otter trading scheme in the North Pacific. But the Spanish venture quickly failed because they could not recruit enough indigenous hunters and 
skinners, and the French, too, shied away from any substantial investment. ${ }^{48}$ With Spain and France out of the running, one man tried to seize this opportunity and proposed his own trading scheme to the government of the newly independent USA. His name was John Ledyard, and he turned the USA's geographic proximity to the riches of the North Pacific into a powerful argument in favor of government investment in the sea otter skin trade.

Born in Groton, Connecticut, Ledyard had sailed with Cook on his third and fatal voyage. Throughout the four-year expedition, Ledyard was an avid, though private, chronicler of the journey. Upon the end of the voyage, all expedition participants were ordered to submit their private journals to the Admiralty, so they would not fall "either from carelessness or design [...] into the hands of printers, and give rise to spurious and imperfect accounts of the voyage." ${ }^{49}$ Ledyard, however, managed to conceal his materials from the Admiralty. Upon his return to the USA in 1782, Ledyard applied to the Connecticut Assembly for the right of exclusive publication of his account, arguing that a history of Cook's last voyage "may be essentially usefull to America in general but particularly to the northern States by opening a most valuable trade across the North Pacific Ocean to China and the East Indies." ${ }^{10}$ The committee charged with the review of his application agreed, judging that such a publication "may be beneficial to these United States \& to the world" and on these grounds, granted him "exclusive right to publish." ${ }^{51}$ Ledyard's Journal of Captain Cook's Last Voyage to the Pacific Ocean, and in Quest of a North-West Passage Between Asia \& America appeared in Hartford, Connecticut in 1783, one year before the official account was published in London, and was the first book in the USA protected by copyright law. ${ }^{52}$

In his Journal, Ledyard, too, wrote about the wonders of the fur trade, and especially the high prices sea otter pelts commanded in Canton. While not bothering to include any details about appearance or physiognomy of the animals he encountered, Ledyard quoted exact sales prices for individual pelts. His numbers matched those stated by Coxe in Account of the Russian Discoveries, confirming that China was the most lucrative market for sea otter skins and other furs. ${ }^{53}$ With his discovery of a possible market for American goods in China, Ledyard tapped into an already existing fascination with all things Chinese among the US political elites. In 1777, while still working as chief staff aide for George Washington, the future Secretary of the Treasury Alexander Hamilton listed a number of goods that the USA was interested in importing from China, among them "diamonds, pearl, gold, silver, copper, iron, sulphur, [...] potters earth (of which is made the porcelain), [...] ambergris and many other of the valuable drugs and gums." ${ }^{54}$ Until Ledyard's discovery, the USA had little to offer in return, which hampered its chances of establishing a balanced import-export economy. Ledyard's plan was to fix this problem by establishing a circular trade route where American vessels, loaded with manufactured goods, departed from the East Coast and sailed around Cape Horn and up the Pacific Coast. Replicating the route Ledyard had sailed on Cook's voyage they would stop at Nootka Sound on the American Pacific coast to trade their manufactured goods for sea otter skins and other furs, winter in Hawai'i, and then head on to Canton to sell their furs. The vessels would bring back Chinese goods like tea, silk, and porcelain, returning via the Indian and Atlantic Oceans. ${ }^{55}$

To get his fur-trading scheme off the ground, Ledyard enlisted the help of Robert Morris, a Philadelphia merchant and superintendent of finance for the US government. ${ }^{56}$ 
Morris was eager to get involved in the China trade and partnered up with an investment firm in New York to have six ships prepared to sail for China. Three ships would be outfitted in Boston to head east carrying American ginseng roots across the Atlantic and the Indian Oceans to Canton, the other three vessels would sail west, around Cape Horn and up the Pacific Coast to be loaded up with furs before they headed on to China. As these plans took shape, Ledyard was elated, writing to his cousin: "I take the lead of the greatest commercial enterprise, that has ever been embarked on in this country; and one of the first moment, as it respects the trade of America." ${ }^{17}$ Ledyard's hopes were soon shattered, though, for Morris' financing scheme fell through, and he and his New York associate only had the money to send one vessel. On 22 February 1784, the Empress of China left the New York harbor to sail east. The ship was not going to load up with Ledyard's precious furs on the way, but carried 30 tons of ginseng harvested in Appalachia. ${ }^{58}$

Not one to be discouraged by the failure of his first Pacific fur-trading venture with Morris, Ledyard sailed to Europe to find backers for his idea overseas. He hoped to get into business with the American expatriate community in France, which consisted of such luminaries as Benjamin Franklin, Thomas Jefferson, and the Revolutionary War hero John Paul Jones. While in France, Ledyard discovered that other governments had already sent trading vessels to the North Pacific. In the wake of the publication and translation of the official account of Cook's Voyage to the Pacific Ocean, a 700-ton ship commissioned by the Russian Empress Catherine the Great headed to the North Pacific, along with ships sent by the French government, vessels owned by the Hudson's Bay Company, and a few private ventures by English merchants. ${ }^{59}$ Thomas Jefferson, who at the time served as US Minister Plenipotentiary to France, carefully observed the British and French activities in the northern parts of the American continent. He was familiar with the official publication of Cook's last voyage, as well as Ledyard's Journal, and had also perused a number of other travel accounts that introduced him to the geography, flora, and fauna of the vast American continent and the two oceans. ${ }^{60}$ Knowing about the many activities of the British and French governments in North America, Jefferson expressed concerns that these countries would eventually establish permanent settlements: "They pretend it is only to promote knowledge," Jefferson wrote, but "I am afraid they have thoughts of colonizing into that quarter.." ${ }^{\prime 1}$ Ledyard's plan to establish an American fur-trading post in the North Pacific, then, was a welcome solution to containing these foreign activities. Despite Jefferson's backing, however, the financing of Ledyard's voyage fell through once again, and English and Russian ventures continued to dominate the fur trade on the American North Pacific coast. ${ }^{62}$

In order to finally stake the American government's claims on the northwestern parts of the American continent, Jefferson came up with a plan of his own. He proposed to John Ledyard "to go by land to Kamschatka, cross in some of the Russian vessels to Nootka sound, fall down into the latitude of the Missouri, and penetrate to, and thro' that, to the United States." ${ }^{\prime \prime 3}$ In the summer of 1786 , then, Ledyard set out to become the first man to cross the American continent from the Pacific to the Atlantic. With Ledyard's arrest in Siberia and subsequent deportation to Poland, though, Jefferson's plan came to an abrupt halt, and terminated for good Ledyard's aspirations to establish a burgeoning fur trade between the American Pacific Coast and China. ${ }^{64}$

Jefferson's expansionist designs and that of the young American republic, by contrast, continued. Elected President of the USA in 1800, Jefferson purchased the vast territory of 
Louisiana from France in 1803. With this acquisition, the size of the USA effectively doubled. Backed by Congress, Jefferson dispatched Meriwether Lewis and William Clark to survey the new territory in 1804. After Ledyard's failed attempt to cross the American continent from the Pacific to the Atlantic, Lewis and Clark were now commissioned to attempt this crossing in the opposite direction. Jefferson's goals for this expedition were clear: Lewis and Clark were

to explore the Missouri river; $\&$ such principal stream of it, as by its course $\&$ communication with the waters of the Pacific ocean, whether the Columbia, Oregon, Colorado or any other river may offer the most direct \& practicable water communication across this continent, for the purpose of commerce." ${ }^{65}$

On 7 November 1805, Lewis and Clark sighted the Pacific Ocean near the mouth of the Columbia River.

While their expedition had been a success and helped the USA establish commercial links across the American continent, the President still had his eye on the transpacific trade. When, in 1808, the New York investor John Jacob Astor approached Jefferson for government backing of his proposed fur-trading settlement on the Oregon Pacific Coast, Jefferson guaranteed Astor "every reasonable patronage \& facility in the power of the Executive." ${ }^{\prime 66}$ The site had been visited by Lewis and Clark three years earlier and was strategically positioned to watch over and contain British, Russian, French, and Spanish activities in the North Pacific. Named Astoria after its founder, the small western outpost became the USA's first permanent settlement west of the Rocky Mountains. ${ }^{67}$ Lauding the inhabitants of Astoria for "planting the germ of an American population on the shores of the Pacific," Jefferson was one step closer to his vision of controlling the transpacific trade. ${ }^{68}$ When Jefferson retired in 1809 after two terms as the President of the USA, his policies had laid the foundation of what he called an "empire for liberty." 69 This empire was not just committed to the extension of the sphere of liberty on the American continent, but was also striving to dominate maritime trade and the race for the acquisition of new domains overseas. ${ }^{70}$

\section{The consequences of transoceanic empire}

While governments on both sides of the Atlantic eagerly capitalized on Ledyard's and Cook's descriptions of the profitability of the sea otter skin trade, Cook's Voyage to the Pacific Ocean and Ledyard's Journal also had a huge impact on private trading schemes. In 1787, two American vessels, the Lady Washington and the Columbia Rediviva set out from Boston on the route Cook and Ledyard had originally sailed. Captained by John Kendrick and Robert Gray, the ships arrived at Nootka Sound in 1789 and established a sound trading connection between the North American Pacific Coast and China. ${ }^{71}$ In the coming decades, hundreds of American private ships followed in their wake. Their numbers increased as still more publications relating to Cook's last voyage flooded the American market. Between 1824 and 1856, Andrew Kippis' condensed account of Cook's life and voyages alone appeared in more than 10 American editions. ${ }^{72}$ Published originally in London in 1788 as The Life of Captain James Cook, Kippis' work contained little information about the sea otter skin trade and misjudged its profitability: "[W]ithout a practicable northern passage," the English edition maintained, "the situation is too remote to 
render it probable that Great Britain should hence ever derive any material advantage."73 While later editions, such as a 1830 Boston version also included this statement in the main body of the text, ${ }^{74}$ the Boston edition's publisher had updated the account and added an appendix, bringing in "new information" and setting "in a clearer and fuller light" other things "which were less perfectly known before."75 The appendix not only cited the numbers on the value of the sea otter skins in Kamchatka and China that had appeared in William Coxe's Account of the Russian Discoveries and Douglas' authorized version of Cook's last voyage, but also proposed to expand the sea otter skin trade to Japan, where "a farther profitable trade is made with some of them." ${ }^{\prime 76}$

With each new edition, more ships seemed to head towards the North Pacific. Between 1788 and 1841, 420 American trading or hunting vessels were sighted in the North Pacific. By then, ships of American provenance outnumbered those from all other countries of origin combined. ${ }^{77}$ Even more, most of the American investors, merchants, captains, and crews that were engaged in the Pacific fur trade came from the northeastern parts of the USA, and from cities that had emerged as publishing centers of the newly independent USA. The American editions of Cook's A Voyage to the Pacific Ocean, Ledyard's Journal, and the many versions of Kippis' compendium were published in cities like New York, Hartford, Philadelphia, Worcester, Boston, and Hudson. "These publication sites," literary historian Michelle Burnham argues, "suggest that a significant audience for Cook's narrative may have consisted of prospective sailors on Pacific [...] hunting voyages, as these crews were drawn largely from the New York and the New England regions."

The European origins of trading and hunting vessels in the North Pacific suggest a similar correlation between the geographic roots of the ships' financiers and crews, and the place of publication of Cook's narrative. Between 1785 and 1841, British, Russian, Portuguese, French, Spanish, and Swedish traders were sighted in the North Pacific. Materials relating to Cook's third voyage continued to appear in places as diverse as Manchester, St. Petersburg, Lisbon, Tours, Madrid, and Uppsala. In 1791, the British fur trader John Meares noted: "To Captain Cook, among other great and public benefits, we are indebted for the commerce of the North West Coast of America, and its profitable application to the China Market." ${ }^{79}$ The European traders competed with the Americans for the best furs, and the highest sales prices in China. Soon, the sea otter became scarce, and the hunters looked further south on the California coast, where they found a different species of sea otter with similar properties. Upon sailing along the North Pacific coast in 1792, naturalist Martin Sauer remarked: "Sea otters are almost forgotten here, [...] [due to the] havoc made among them by the hunters." ${ }^{80}$ By 1835 , sea otters had become a rare sight in California as well, and hunters began to go after every marine animal that promised commercial profit. In the nineteenth century, fur seals and whales became favorite targets for the hunters, and along with the sea otter, were brought close to extinction. ${ }^{81}$

The great hunt for marine mammals had severe consequences not only for the natural environment of the North Pacific, but also for those who depended on this environment for their livelihood. Already in 1753, Steller noted how the clothing habits of the North Pacific indigenous populations changed because they had to give up all their furs to Russian traders. ${ }^{82}$ Even more, with the depletion of the local animal population, important food sources also vanished, leading to the slow displacement of indigenous populations as they followed their food. Throughout the nineteenth century, however, hunting and trading practices remained largely unregulated. In 1911, 
the International Fur Seal Treaty finally banned the hunting of sea otters, ensuring its survival. ${ }^{83}$

In tracing the sea otter skin trade through most of the eighteenth century, I have attempted to combine my analysis of the ocean's resources beneath the waves with an approach that stays on the ocean's surface, conceiving of water as a means of transportation, connection, circulation, transmission, and exchange. This two-pronged approach has illustrated the complexity of the relationship between animals and humans in the North Pacific while exposing the transoceanic implications of a decidedly local phenomenon. After the discovery of the sea otter in the North Pacific, it was an Atlantic publishing network, ranging from London, Edinburgh, Dublin, Paris, Rotterdam, Philadelphia, New York, and Boston that revealed the commercial value of its skin to a large readership both in Europe and the USA. What began with the publication of Cook's and Ledyard's accounts about their travels into the North Pacific turned into one the largest transoceanic trading ventures ever operated by either private or government agents.

The American interest in expanding its territories into the Pacific only intensified during the nineteenth century. In 1838, the US government sent its own expedition into the Pacific Ocean. Modeled after the voyages of Cook and others, the US Exploring Expedition was to survey the waters, islands, and lands in or adjacent to the Pacific and help establish the USA among the world's leading scientific and commercial powers. In 1867, the US bought Alaska from the Russian Empire, and in 1898 Hawai'i was annexed. In the same year, the USA acquired the Spanish Pacific possessions of the Philippines and Guam, taking control, two years later, of the Pacific island of Samoa. In the Atlantic, the US occupied Puerto Rico and Cuba, and established a US Territory in Panama, a region of strategic importance because it could, and would, eventually provide the long sought-after connection between the Atlantic and the Pacific Oceans. The seeds of these ventures were planted in the founding days of the USA, which was never merely an Atlantic, Pacific, or continental nation, but rather, from its inception, a transoceanic empire constantly in the process of defining and re-defining its relations with and beyond the seas.

\section{Notes}

1. See, for example, Goetzmann, New Lands, 1.

2. For a critique of the "ages of discovery" thesis, see Robinson "Science and Exploration," 31-32.

3. Bleichmar, Visible Empire, 7.

4. Igler, The Great Ocean, 134. For more on the relationship between science and exploration, see Robinson, "Science and Exploration," and Stern, "Exploration and Enlightenment."

5. For comprehensive overviews of the activities of European powers in the Pacific, see, for example, Chaplin, "The Pacific"; Thomas, "The Age of Empire"; Kennedy, Reinterpreting Exploration; and Haycox, Barnett, and Liburd, Enlightenment and Exploration. For the activities of specific European empires, see Gascoigne, Encountering; Dunmore, Visions and Realities; Buschmann, Iberian Visions; Jones, Empire of Extinction; and Boomgaard, Science. For early American activities in the North Pacific, see Igler, The Great Ocean, 3-42. For a study of the impact of European Pacific exploration on indigenous cultures see, for example, Thomas, Islanders; and Miller, Kodiak Kreol.

6. This essay has been inspired by the scholarship of historians Matt Matsuda, David Igler, and John Gascoigne, who emphasize that we cannot speak of one Pacific Ocean, but rather of a Pacific World that consists of multiple seas, cultures, and peoples, and the exchanges, flows, connections, and overlapping transits between them. My focus on the sea otter was 
informed by ecocritical interventions and "beneath the waves" approaches exemplified in the works of Ryan Tucker Jones, Kären Wigen, and Hester Blum. See Matsuda, Pacific Worlds, 2-3; Igler, The Great Ocean, 10-11; Gascoigne, Encountering, xiv; Jones, "Running," 350; Wigen, "Oceans of History," 721; and Blum, "Introduction," 151. An important alternative to the rim discourse that focuses on oceanic epistemologies has also been proposed by the Fijian scholar Epeli Hau'ofa. See Hau'ofa, "Our Sea," 32-33.

7. I am thinking here of Giles, Antipodean America; Shu and Pease, American Studies; and Taketani, The Black Pacific.

8. Shu and Pease, "Introduction," 8; Rowe, "Transpacific Studies," 261.

9. For an assessment of the utility of a continental approach to American history, see Wood, "From Atlantic History" and Barr, "Beyond." For examples of scholarly work written in that vein, see Taylor, American Colonies; Fenn, Pox Americana; and Mapp, The Elusive West.

10. Mapp, The Elusive West and the Contest of Empire, 1713-1763 is a notable exception.

11. Burnham, "Early America," 954.

12. In her article "Trade, Time, and the Calculus of Risk" Michelle Burnham has pointed to the very fruitful connections between Pacific exploration and Atlantic publishing networks. For more on how print culture scholarship opened up new lines of inquiry for the study of exploration, see, for example, Craciun, "Oceanic Voyages"; Withers and Keighren, "Travels into Print" and Sher, The Enlightenment.

13. In the wake of Amy Kaplan and Donald E. Pease's 1993 volume Cultures of United States Imperialism much has been done to reconceptualize the USA as an empire, especially from the nineteenth century to the present. Important works include Stoler, Haunted; "Tense and Tender"; "On Degrees"; Rowe, Literary Culture; and Kaplan, The Anarchy. Scholarship that considers the imperial dimensions of early America is still comparatively rare, but growing. See, for example, Burnham, "Early America"; Doolen, Fugitive Empire; White, "Early American Nations"; Onuf, Jefferson's Empire; Zagarri, "The Significance"; Immerman, Empire for Liberty; and Larkin, "Nation and Empire." With the exception of Burnham, the texts listed above do not include the USA's maritime ambitions in their study of early American empire.

14. For more on the Second Kamchatka Expedition, see Jones, Empire of Extinction, 21-39.

15. Müller quoted in Jones, Empire of Extinction, 44.

16. Steller, Ausführliche Beschreibung, 164 (my translation). Translations, unless otherwise noted, are my own.

17. Ibid., 161-185.

18. Ibid., 175.

19. Ibid., 174.

20. Ibid., 185-208.

21. Ibid., 198.

22. Coxe, An Account, viii.

23. Jones, Empire of Extinction, 142-147.

24. Coxe, An Account, viii.

25. Ibid., viii.

26. Ibid., viii-ix.

27. Ibid., 13-14.

28. Salmond, The Trial, 408-416.

29. The work's complete title is A Voyage to the Pacific Ocean. Undertaken by the Command of His Majesty, for making Discoveries in the Northern Hemisphere. To determine the Position and Extent of the West Side of North America: Its Distance from Asia and the Practicability of a Northern Passage to Europe. Performed under the directions of Captains Cook, Clerke, and Gore, in His Majesty's Ships the Resolution and Discovery. In the Years 1776, 1777, 1778, 1779 and 1780 .

30. For a brief assessment of Douglas' work as an editor and the differences between manuscript version and published account, see MacLaren, "Exploration/Travel Literature," 39-56 and Williams, The Death, 44-60. For an in-depth study of the expedition's stay in the North Pacific and the discrepancies between its representation in Cook's journal and the authorized version, see 
Currie, Constructing Colonial Discourse and Clayton, Islands of Truth. For a critical edition of Cook's journal, see J. C. Beaglehole, The Journals.

31. In 2005, this sum would have amounted to $£ 296.97$ (see Currency Converter of the National Archives, London).

32. Quoted in Williams, The Death, 23.

33. Williams, The Death, 23.

34. For more on the reception of the official account of Cook's third voyage, see Williams, The Death, 22-24.

35. Cook, A Voyage, Vol. II, 295.

36. Ibid.

37. Ibid.

38. Ibid.

39. Ibid.

40. Cook, A Voyage, Vol. II, 296. To further corroborate the commercial value of the sea otter furs, Douglas also added a footnote that quoted directly from Coxe's Account of Russian Discoveries: "Old and middle-aged sea otter skins," it read, "[were] sold, at Kiachta, by the Russians to the Chinese, from 80 to 100 rubles a skin" (ibid.) As Coxe's volume was only published after Cook's death, the footnote citing Coxe's numbers provides another fine example of Douglas' editorial interventions.

41. Cook, A Voyage, Vol. III, 437.

42. Igler, The Great Ocean, 106.

43. Cook, A Voyage, Vol. III, 437.

44. Cook, A Voyage, Vol. III, 441; 437-441.

45. I am referring here to the following editions of $A$ Voyage to the Pacific Ocean: Dublin (Chamberlaine, 1784), Paris (Hôtel de Thou, 1785), Rotterdam (Bothal en D. Vis, 1788), Anspach (Messerer, 1789), and Turin (Stampatore and Librajo, 1791).

46. See, for example, the following abbreviated versions: London (Kearsley, 1784), Paris (Moutard, 1785), Berlin (Haude und Spener, 1789), and Dublin (M'Donnel, 1801).

47. The seven American editions of $A$ Voyage to the Pacific Ocean that contain the sea otter episode are: Philadelphia (Johnson, 1793), Worcester (Thomas, 1795), Philadelphia (Woodward for Johnson, 1796), New York (Tiebout and O'Brien for Gomez, 1796), Boston (Manning and Loring for Thomas, Andrews, and D. West, 1797), New York (Long for Duyckinck, 1814), and Philadelphia (Maxwell for Desilver, 1818). Of the four remaining editions, two essentially end with the death of Captain Cook and therefore do not cover the expedition's stay in Canton. These editions are New York (Mott and Hurtin for Gomez, 1795) and New York (Durell, 1796). The Hudson edition did not more than mention the sea otter (Stoddard, 1809). I have been unable to consult the 1793 New York edition (Gomez, 1793).

48. For more on the Spanish and French forays into the sea otter skin trade, see Igler, The Great Ocean, 107; Gibson, Otter Skins, 18-21; La Pérouse, Voyage, Vol. 4, 162-172.

49. Cook, A Voyage, Vol. III, 417.

50. Quoted in Gray, The Making, 97.

51. Quoted in Lehmann-Haupt, Wroth, and Silver, The Book, 102.

52. Lehmann-Haupt, Wroth, and Silver, The Book, 101-102.

53. Ledyard, A Journal, 70.

54. Quoted in Dolin, When America, 64-65.

55. Zug, American Traveler, 128.

56. Gray, The Making, 101.

57. Quoted in Dolin, When America, 12.

58. Gray, The Making, 105-107; Dolin, When America, 11-13.

59. Gray, The Making, 110.

60. Sowerby, Catalogue, 147-149.

61. Quoted in Gray, The Making, 121.

62. Gray, The Making, 109-123; Zug, American Traveler, 149-159.

63. Jefferson to Paul Allen, 18 August 1813. 
64. Gray, The Making, 124-127, 130-132, 136-139, 146-152.

65. Jefferson to Meriwether Lewis, 20 June 1803.

66. Jefferson to John Jacob Astor, 13 April 1808.

67. For more on the founding of Astoria, see Ronda, Astoria, esp. 40-64.

68. Jefferson to John Jacob Astor, 24 May 1812.

69. Jefferson to James Madison, 27 April 1809.

70. For more on the maritime ambitions of the early USA, see Rouleau, With Sails, esp. 1-41; Mackenthun, Fictions, 69-72; Chaplin, "Knowing," 89-96; Rowe, "Transpacific," 264; and Shu and Pease, "Introduction," 10.

71. Igler, The Great Ocean, 3-4.

72. Andrew Kippis' work was published in the USA as A Narrative of the Voyages round the world, performed by Captain James Cook: With an account of his life during the previous and intervening periods. It appeared, for example, in New York (Fanshaw, 1824), Boston (Whitaker, 1828), Boston (Whitaker, 1830), Philadelphia (Johnson, 1832), Cincinnati (Morgan, Sanxay, and James, 1833), Philadelphia (Anners, 1844), New York (Harper, 1844), New York (Leavitt and Allen, 1853), Philadelphia (Leary and Getz, 1853), and New York (Leavitt and Allen, c.1854).

73. Kippis, The Life, 430.

74. Kippis, A Narrative, 119.

75. Ibid., viii.

76. Ibid., 196.

77. Gibson, Otter Skins, 299-310.

78. Burnham, "Trade," 443.

79. Meares, Voyages, Vol. II, 280-281.

80. Quoted in Igler, The Great Ocean, 107.

81. Ibid., 103.

82. Steller, Ausführliche Beschreibung, 190.

83. Jones, Empire of Extinction, 159-160, 241.

\section{Disclosure statement}

No potential conflict of interest was reported by the author.

\section{Notes on contributor}

Juliane Braun is a postdoctoral research fellow at the University of Bonn. She is currently working on her second book, tentatively titled Translating the Pacific: Imperial Imaginations, Nature Writing, and Early Modern Print Cultures. She completed this essay with the generous support of the Gielen-Leyendecker Foundation.

\section{Bibliography}

Barr, Juliana. "Beyond the 'Atlantic World': Early American History as Viewed from the West." OAH Magazine of History 25 (2011): 13-18.

Beaglehole, J. C., ed. The Journals of Captain James Cook. Vol. III: The Voyage of the Resolution and Discovery 1776-1780. Cambridge: Published for the Hakluyt Society at the University Press, 1967.

Bleichmar, Daniela. Visible Empire: Botanical Expeditions and Visual Culture in the Hispanic Enlightenment. Chicago: University of Chicago Press, 2012.

Blum, Hester. "Introduction: Oceanic Studies." Atlantic Studies 10, no. 2 (2013): 151-155.

Boomgaard, Peter, ed. Science in the Making: Dutch Colonial Scholarship in Comparative Global Perspective. New York: Palgrave Macmillan, 2013.

Burnham, Michelle. "Early America and the Revolutionary Pacific." PMLA 128, no. 4 (2013): 953-960.

Burnham, Michelle. "Trade, Time, and the Calculus of Risk in Early Pacific Travel Writing." Early American Literature 46, no. 3 (2011): 425-447. 
Buschmann, Rainer F. Iberian Visions of the Pacific Ocean, 1507-1899. Basingstoke: Palgrave Macmillan, 2014.

Chaplin, Joyce E. "Knowing the Ocean: Benjamin Franklin and the Circulation of Atlantic Knowledge." In Science and Empire in the Atlantic World, edited by James Delbourgo and Nicholas Dew, 73-96. New York: Routledge, 2008.

Chaplin, Joyce E. "The Pacific Before Empire, c. 1500-1800." In Pacific Histories: Ocean, Land, People, edited by David Armitage and Alison Bashford, 53-74. Basingstoke: Palgrave Macmillan, 2014.

Clayton, Daniel W. Islands of Truth: The Imperial Fashioning of Vancouver Island. Vancouver: University of British Columbia Press, 2000.

Cook, James. A Voyage to the Pacific Ocean. Undertaken, by the Command of His Majesty, for Making Discoveries in the Northern Hemisphere... Performed under the Direction of Captains Cook, Clerke, and Gore, ... Vol. I. and II. Written by Captain James Cook, F.R.S. Vol. III. by Captain James King. London: Strahan, Nicol, and Cadell, 1784.

Coxe, William. Account of the Russian Discoveries Between Asia and Russia: To Which Are Added, the Conquest of Siberia, and the History of the Transaction and Commerce between Russia and China. London: Cadell, 1780.

Craciun, Adriana. "Oceanic Voyages, Maritime Books, and Eccentric Inscriptions." Atlantic Studies 10, no. 2 (2013): 170-196.

Currie, Noel Elizabeth. Constructing Colonial Discourse: Cook at Nootka Sound, 1778. Montreal: McGillQueen's University Press, 2005.

Dolin, Eric Jay. When America First Met China: An Exotic History of Tea, Drugs, and Money in the Age of Sail. New York: Liveright, 2012.

Doolen, Andy. Fugitive Empire: Locating Early American Imperialism. Minneapolis: University of Minnesota Press, 2005.

Dunmore, John. Visions and Realities: France in the Pacific, 1695-1995. Waikanae: Heritage Press, 1997.

Fenn, Elizabeth A. Pox Americana: The Great Smallpox Epidemic of 1775-82. New York: Hill and Wang, 2001.

Gascoigne, John. Encountering the Pacific in the Age of Enlightenment. Port Melbourne: Cambridge University Press, 2014.

Gibson, James R. Otter Skins, Boston Ships, and China Goods: The Maritime Fur Trade of the Northwest Coast, 1785-1841. Montreal: McGill-Queen's University Press, 1992.

Giles, Paul. Antipodean America: Australasia and the Constitution of U.S. Literature. Oxford: Oxford University Press, 2013.

Goetzmann, William H. New Lands, New Men: America and the Second Great Age of Discovery. Austin: Texas State Historical Association, 1995 (Reprint).

Gray, Edward G. The Making of John Ledyard: Empire and Ambition in the Life of an Early American Traveler. New Haven, CT: Yale University Press, 2007.

Hau'ofa, Epeli. "Our Sea of Islands." In We Are the Ocean: Selected Works, 27-40. Honolulu: University of Hawai'i Press, 2008.

Haycox, Stephen W., James K. Barnett, and Caedmon A. Liburd. Enlightenment and Exploration in the North Pacific, 1741-1805. Seattle: Published for the Cook Inlet Historical Society in the Anchorage Museum of History and Art by the University of Washington, 1997.

Igler, David. The Great Ocean: Pacific Worlds from Captain Cook to the Gold Rush. Oxford: Oxford University Press, 2013.

Immerman, Richard H. Empire for Liberty: A History of American Imperialism from Benjamin Franklin to Paul Wolfowitz. Princeton, NJ: Princeton University Press, 2010.

Jefferson, Thomas to James Madison, 27 April 1809. Library of Congress. Washington DC, Manuscript Division (149). 24 February 2017. https://www.loc.gov/exhibits/jefferson/149.html.

Jefferson, Thomas to John Jacob Astor, 13 April 1808. Founders Online. National Archives, Washington, DC. Accessed 24 February 2017. http://founders.archives.gov/documents/ Jefferson/99-01-02-7829.

Jefferson, Thomas to John Jacob Astor, 24 May 1812. Founders Online. National Archives, Washington, DC. http://founders.archives.gov/documents/Jefferson/03-05-02-0056. 
Jefferson, Thomas to Meriwether Lewis, 20 June 1803. Library of Congress. Washington DC, Manuscript Division (57). 24 February 2017. https://www.loc.gov/exhibits/lewisandclark/ transcript57.html.

Jefferson, Thomas to Paul Allen, 18 August 1813. Founders Online. National Archives, Washington, DC. 24 February 2017. http://founders.archives.gov/documents/Jefferson/03-06-02-0341-0002.

Jones, Ryan Tucker. Empire of Extinction: Russians and the North Pacific's Strange Beasts of the Sea, 1741-1867. Oxford: Oxford University Press, 2014.

Jones, Ryan Tucker. "Running into Whales: The History of the North Pacific from Below the Waves." American Historical Review 118 (April 2013): 349-377.

Kaplan, Amy. The Anarchy of Empire in the Making of U.S. Culture. Cambridge, MA: Harvard University Press, 2002.

Kaplan, Amy, and Donald E. Pease, eds. Cultures of United States Imperialism. Durham, NC: Duke University Press, 1993.

Kennedy, Dane Keith, ed. Reinterpreting Exploration: The West in the World. New York: Oxford University Press, 2014.

Kippis, Andrew. The Life of Captain James Cook. London: Nicol and Robinson, 1788.

Kippis, Andrew. A Narrative of the Voyages Round the World Performed by Captain James Cook, with an Account of His Life During the Previous and Intervening Periods. Boston: Whitaker, 1830.

La Pérouse, Jean-François Galaup de. Voyage de La Pérouse autor du monde. Vol. 4. Paris: Plassan, 1798.

Larkin, Edward. "Nation and Empire in the Early US." American Literary History 22, no. 3 (2010): 501-526.

Ledyard, John. A Journal of Captain Cook's Last Voyage to the Pacific Ocean; and in Quest of a NorthWest Passage, between Asia \& America, Performed in the Years 1776, 1777, 1778 and 1779. Illustrated with a Chart, Shewing the Tracks of the Ships Employed in this Expedition. Faithfully Narrated from the Original Ms. of Mr. John Ledyard. Hartford: Patten, 1783.

Lehmann-Haupt, Hellmut, Lawrence C. Wroth, and Rollo G. Silver. The Book in America: A History of the Making and Selling of Books in the United States. 2nd ed. New York: Bowker, 1951.

Mackenthun, Gesa. Fictions of the Black Atlantic in American Foundational Literature. London: Routledge, 2004.

MacLaren, I. S. "Exploration/Travel Literature and the Evolution of the Author." International Journal of Canadian Studies/Revue international d'études canadiennes 5, Spring/Printemps (1992): 39-68.

Mapp, Paul W. The Elusive West and the Contest for Empire, 1713-1763. Chapel Hill, NC: University of North Carolina Press, 2011.

Matsuda, Matt K. Pacific Worlds: A History of Seas, Peoples, and Cultures. Cambridge: Cambridge University Press, 2012.

Meares, John. Voyages Made in the Years 1788 and 1789, from China to the North West Coast of America: To Which Are Prefixed an Introductory Narrative of a Voyage Performed in 1786, from Bengal, in the Ship Nootka; Observations on the Probable Existence of a North West Passage; and Some Account of the Trade Between the North West Coast of America and China; and the Latter Country and Great Britain. London: Walter, 1790.

Miller, Gwenn A. Kodiak Kreol: Communities of Empire in Early Russian America. Ithaca, NY: Cornell University Press, 2010.

Onuf, Peter S. Jefferson's Empire: The Language of American Nationhood. Charlottesville: University Press of Virginia, 2000.

Robinson, Michael F. "Science and Exploration." In Reinterpreting Exploration: The West in the World, edited by Dane Kennedy, 21-37. New York: Oxford University Press, 2014.

Ronda, James P. Astoria and Empire. Lincoln: University of Nebraska Press, 1990.

Rouleau, Brian. With Sails Whitening Every Sea: Mariners and the Making of an American Maritime Empire. Ithaca, NY: Cornell University Press, 2014.

Rowe, John Carlos. Literary Culture and U.S. Imperialism: From the Revolution to World War II. Oxford: Oxford University Press, 2000.

Rowe, John Carlos. "Transpacific Studies and the Cultures of U.S. Imperialism." In American Studies as Transnational Practice: Turning Toward the Transpacific, edited by Yuan Shu and Donald E. Pease, 259-275. Hanover, NH: Dartmouth College Press, 2015. 
Salmond, Anne. The Trial of the Cannibal Dog: The Remarkable Story of Captain Cook's Encounters in the South Seas. New Haven, CT: Yale University Press, 2003.

Sher, Richard. The Enlightenment and the Book. Chicago: University of Chicago Press, 2006.

Shu, Yuan, and Donald E. Pease, eds. American Studies as Transnational Practice: Turning Toward the Transpacific. Hanover, NH: Dartmouth College Press, 2015.

Shu, Yuan, and Donald E. Pease. "Introduction: Transnational American Studies and the Transpacific Imaginary." In American Studies as Transnational Practice: Turning Toward the Transpacific, edited by Yuan Shu and Donald E. Pease, 1-35. Hanover, NH: Dartmouth College Press, 2015.

Sowerby, E. Millicent, comp. Catalogue of the Library of Thomas Jefferson. Vol. IV. Washington, DC: Library of Congress, 1952-1959.

Steller, Georg Wilhelm. Ausführliche Beschreibung von sonderbaren Meerthieren, mit Erläuterungen und nöthigen Kupfern versehen. Halle: Kümmel, 1753.

Stern, Philip J. "Exploration and Enlightenment." In Reinterpreting Exploration: The West in the World, edited by Dane Kennedy, 54-79. New York: Oxford University Press, 2014.

Stoler, Ann Laura, ed. Haunted by Empire: Geographies of Intimacy in North American History. Durham, NC: Duke University Press, 2006.

Stoler, Ann Laura. "On Degrees of Imperial Sovereignty." Public Culture 18, no. 1 (2006): 125-146.

Stoler, Ann Laura. "Tense and Tender Ties: The Politics of Comparison in North American History and (Post)Colonial Studies." In Haunted by Empire: Geographies of Intimacy in North American History, edited by Ann Laura Stoler, 23-67. Durham, NC: Duke University Press, 2006.

Taketani, Etsuko. The Black Pacific Narrative: Geographic Imaginings of Race and Empire between the World Wars. Hanover, NH: Dartmouth College Press, 2014.

Taylor, Alan. American Colonies. New York: Viking, 2001.

Thomas, Nicholas. "The Age of Empire in the Pacific." In Pacific Histories: Ocean, Land, People, edited by David Armitage and Alison Bashford, 75-96. Basingstoke: Palgrave Macmillan, 2014.

Thomas, Nicholas. Islanders: The Pacific in the Age of Empire. New Haven: Yale University Press, 2010.

White, Ed. "Early American Nations as Imagined Communities." American Quarterly 56, no. 1 (2004): 49-81.

Wigen, Kären. "Oceans of History." The American Historical Review 111 (2006): 717-721.

Williams, Glyndwr. The Death of Captain Cook: A Hero Made and Unmade. Cambridge, MA: Harvard University Press, 2008.

Withers, Charles, and Innes Keighren. "Travels into Print: Authoring, Editing and Narratives of Travel and Exploration, c.1815-c.1857." Transactions of the Institute of British Geographers 36, no. 4 (2011): 560-573.

Wood, Peter H. "From Atlantic History to a Continental Approach." In Atlantic History: A Critical Appraisal, edited by Jack P. Greene and Philip D. Morgan, 279-289. Oxford: Oxford University Press, 2009.

Zagarri, Rosemarie. "The Significance of the Global Turn for the Early American Republic: Globalization in the Age of Nation Building." Journal of the Early Republic 31, no. 1 (2011): 1-37.

Zug, James. American Traveler: The Life and Adventures of John Ledyard, the Man Who Dreamed of Walking the World. New York: Basic, 2005. 